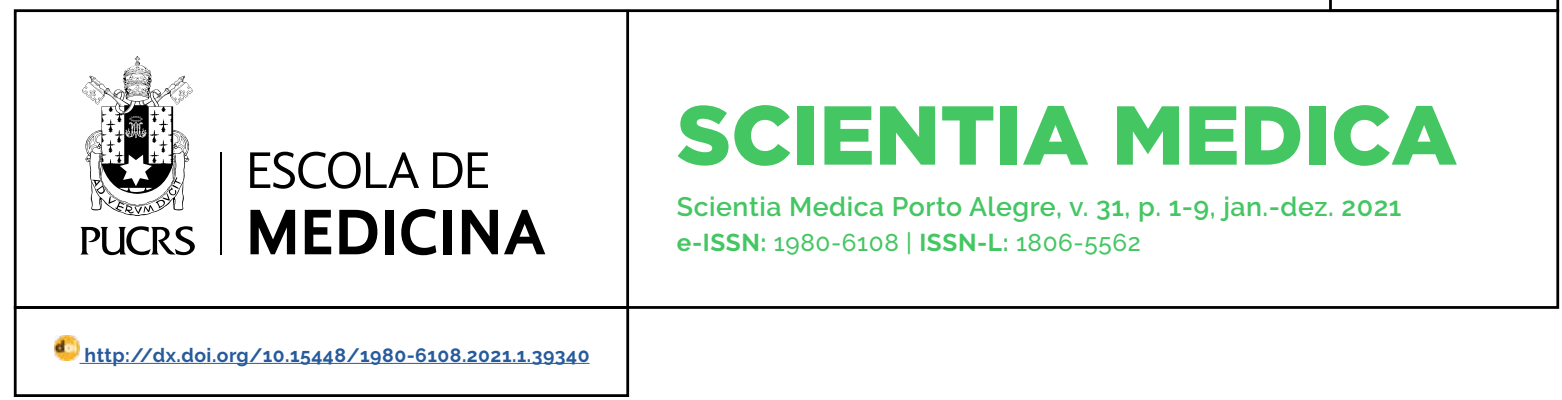

REVIEW ARTICLE

\title{
Remote and non-invasive monitoring of patients with COVID-19 by smartphone
}

\author{
Monitoramento remoto e não invasivo de pacientes com COVID-19 pelo smartphone
}

\author{
Thiago Mazzu- \\ Nascimento ${ }^{1}$ \\ orcid.org/0000-0002-1693-9149 \\ thiagomazzu@gmail.com
}

\section{Danilo Nogueira Evangelista ${ }^{1}$}

orcid.org/0000-0002-4555-9436

daniloevangelista1992@gmail.com

\section{Obeedu Abubakar ${ }^{1}$}

orcid.org/0000-0001-6086-145X obeeduabubakaro01@gmail.com

\section{Bernardino Geraldo Alves Souto ${ }^{1}$}

orcid.org/0000-0003-4083-3050 bernardino@ufscar.br

\section{Lucas Vinicius \\ Domingues $^{2}$}

orcid.org/0000-0002-9317-3714

lucasvd@estudante.ufscar.br

\section{Diego Furtado Silva ${ }^{2}$ \\ orcid.org/0000-0002-5184-9413 diego.fsilva@gmail.com}

\section{Carlos Alberto Nogueira-de-Almeida ${ }^{1}$ orcid.org/0000-0003-1272-4404 dr.nogueira@me.com}

Received on: Oct.12 ${ }^{\text {th }}, 2020$. Approved on: Mar. $26^{\text {th }}, 2021$. Published on: April. 13th, 2021.

\section{(c) (i)}

Artigo está licenciado sob forma de uma licença Creative Commons Atribuição 4.0 Internacional.
Abstract: The pandemic caused by the new coronavirus (SARS-COV-2) has led to more than two million deaths in the world by March 2021. The worldwide call to reduce transmission is enormous. Recently, there has been a rapid growth of telemedicine and the use of mobile health (mHealth) in the context of the COVID-19 pandemic. Smartphone accessories such as a flashlight, camera, microphone, and microprocessor can measure different clinical parameters such as oxygen saturation, blood pressure, heart rate, breathing rate, fever, pulmonary auscultation, and even voice analysis. All these parameters are of great clinical importance when evaluating suspected patients of COVID-19 or monitoring infected patients admitted in various hospitals or in-home isolation. In remote medical care, the results of these parameters can be sent to a call center or a health unit for interpretation by a qualified health professional. Thus, the patient can receive orientations or be immediately referred for in-patient care. The application of machine learning and other artificial intelligence strategies assume a central role in signal processing and are gaining much space in the medical field. In this work, we present different approaches for evaluating clinical parameters that are valuable in the case of COVID-19 and we hope that soon all these parameters can be measured by a single smartphone application, facilitating remote clinical assessments.

Keywords: coronavirus infections, mobile health, pandemics, smartphone, telemedicine

Resumo: A pandemia causada pelo novo coronavírus (SARS-COV-2) foi a responsável por mais de dois milhões de mortes no mundo até março de 2021. O apelo mundial para reduzir a transmissão é enorme. Recentemente, houve um rápido crescimento do uso de telemedicina e saúde móvel (mHealth) no contexto da pandemia causada pela doença COVID-19. Os acessórios dos smartphones, como lanterna, câmera, microfone, bem como o microprocessador podem analisar diferentes parâmetros clínicos, tais como, a saturação de oxigênio, pressão arterial, frequência cardiaca, frequência respiratória, febre, ausculta pulmonar e até mesmo análise da voz. Todos esses parâmetros são de grande importância clínica na avaliação de pacientes suspeitos de COVID-19 ou no monitoramento de pacientes infectados que estão no hospital ou em isolamento domiciliar. No atendimento médico remoto, os resultados desses parâmetros podem ser enviados a uma central de atendimento ou à unidade de saúde para que o resultado seja interpretado por profissional de saúde qualificado. Assim, o paciente pode receber orientações ou ser encaminhado imediatamente para internação. A aplicação de aprendizado de máquina e outras estratégias de inteligência artificial assumem um papel central no processamento de sinais e vêm ganhando muito espaço na área médica. Neste trabalho, apresentamos diferentes abordagens para avaliação de parâmetros clínicos valiosos no caso do COVID-19 e esperamos que em breve todos esses parâmetros possam ser mensurados em um único aplicativo para smartphone, facilitando avaliações clinicas à distância.

Palavras-Chave: infecções por Coronavirus, saúde móvel, pandemia, smartphone, telemedicina 
ABBREVIATIONS: COVID-19, Coronavirus disease 2019; LED, light-emitting diode; mHealth, mobile health; SARS, Severe acute respiratory syndrome.

\section{Introduction}

The initial cases of coronavirus disease 2019 (COVID-19), caused by SARS-COV-2, appeared in Wuhan, China, and quickly spread to more than 180 countries (1). The disease was transmitted across different continents, making it a pandemic leading to negative impacts on people's health, health systems, and the economy (2).

World Health Organization Coronavirus dashboard informed that the new coronavirus infection in the world reached a total of 123,902,242 cases on 24rd March 2021. Among these cases, 2,727,837 deaths were registered. The United States recorded 29,592,831 cases and 538,244 deaths, with the country having the highest number of victims and deaths. The second country with the highest number of cases and deaths by COVID-19 is Brazil with 12,047,526 cases and 295,425 deaths. India is the third country with the highest number of COVID-19 infections representing $11,734,058$ cases, and Mexico is the third country with the highest number of deaths, with 198,239 confirmed deaths. From March 17 to March 24 Brazil led the number of cases $(527,917)$ and the number of deaths $(16,139)$, exceeding the average of 2,300 daily deaths (3).

SARS-COV-2 is a virus with an envelope and a lipid bilayer that fuses with the host cell membrane and releases viral RNA in the cell cytoplasm, particularly in the pneumocytes. The initial virus takes over the cellular machinery to replicate, produce viral proteins, and assemble new viruses that can infect other cells, thus initiating a series of viral multiplication. Transmission is rapid and spreads from person-to-person via air or indirectly, by contact with contaminated secretions, such as droplets of saliva, with an average incubation period of 3 to 9 days $(1,4,5)$.

COVID-19 is a zooanthroponosis caused by a virus belonging to the Coronaviridae family and can lead to respiratory disease that, in many cases can result in serious systemic repercussions (6).
The disease progression is rapid, capable of causing diffuse alveolar lesions, large inflammatory infiltrates, desquamation of pneumocytes, pulmonary edema, leading to acute respiratory distress. Other organs such as the liver, kidney, or nervous system, for example, can also be affected. This occurrence demonstrates the destructive power of this virus or its interaction with the immune system. It can be asymptomatic in many cases but, the initial symptoms can be similar to a flu syndrome (runny nose, cough, fever, etc.). However, when the disease progresses to a serious form, the presence of high fever, dyspnea, fatigue, anorexia, a significant decrease in oxygen saturation, and coagulopathies are often observed $(5,7)$.

The gold standard diagnostic is the detection of the viral RNA sequence using the Real-Time Polymerase Chain Reaction (RT-PCR) in nasooropharyngeal smears. However, Point-of-care testing (POCTs) are being used to detect IgG and IgM anti-COVID-19 antibodies (8). In cases of COVID-19, patients' vital signs need to be monitored. As the disease worsens, in addition to vital signs, it is essential to monitor respiratory, renal, and cardiac functions, as well as requesting laboratory tests to assess hematological, coagulation, and biochemical profile (6).

The developments of new diagnostic methods are advancing rapidly and increasingly seeking to be less invasive, low cost, and accessible to the entire population $(9,10)$. The introduction of mobile health and smartphone application for clinical evaluation and monitoring is a new trend and is already part of our daily life (11). Smartphone accessories (flashlight, camera, and microphone), as well as the processing capacity, allow these devices to monitor vital signs and even diseases such as diabetes $(12,13)$ and anemia (14).

Global health systems are facing a great challenge in light of the huge number of COVID-19 cases. Telehealth practice is emerging as a way to help health systems $(15,16)$. Although there is still resistance to implementing telemedicine, there are signs of improvements. The pandemic scenario is influencing our medical practice; among other things, it is accelerating the advances related to 
the use of telemedicine. Some authors are indeed encouraging the use of telemedicine as a strategy to avoid contamination risk at hospitals and clinics (17). The Brazilian Federal Council of Medicine is responsible for supervising and regulating medical practice in Brazil, manifested by letter on March 19 , 2020, the possibility of incorporating telemedicine, exceptionally, during the COVID-19 pandemic (15).

Here, we present different approaches using the smartphone to monitor patients with COVID-19. Figure 1 illustrates the different clinical parameters that can be analyzed by the smartphone and its several accessories.

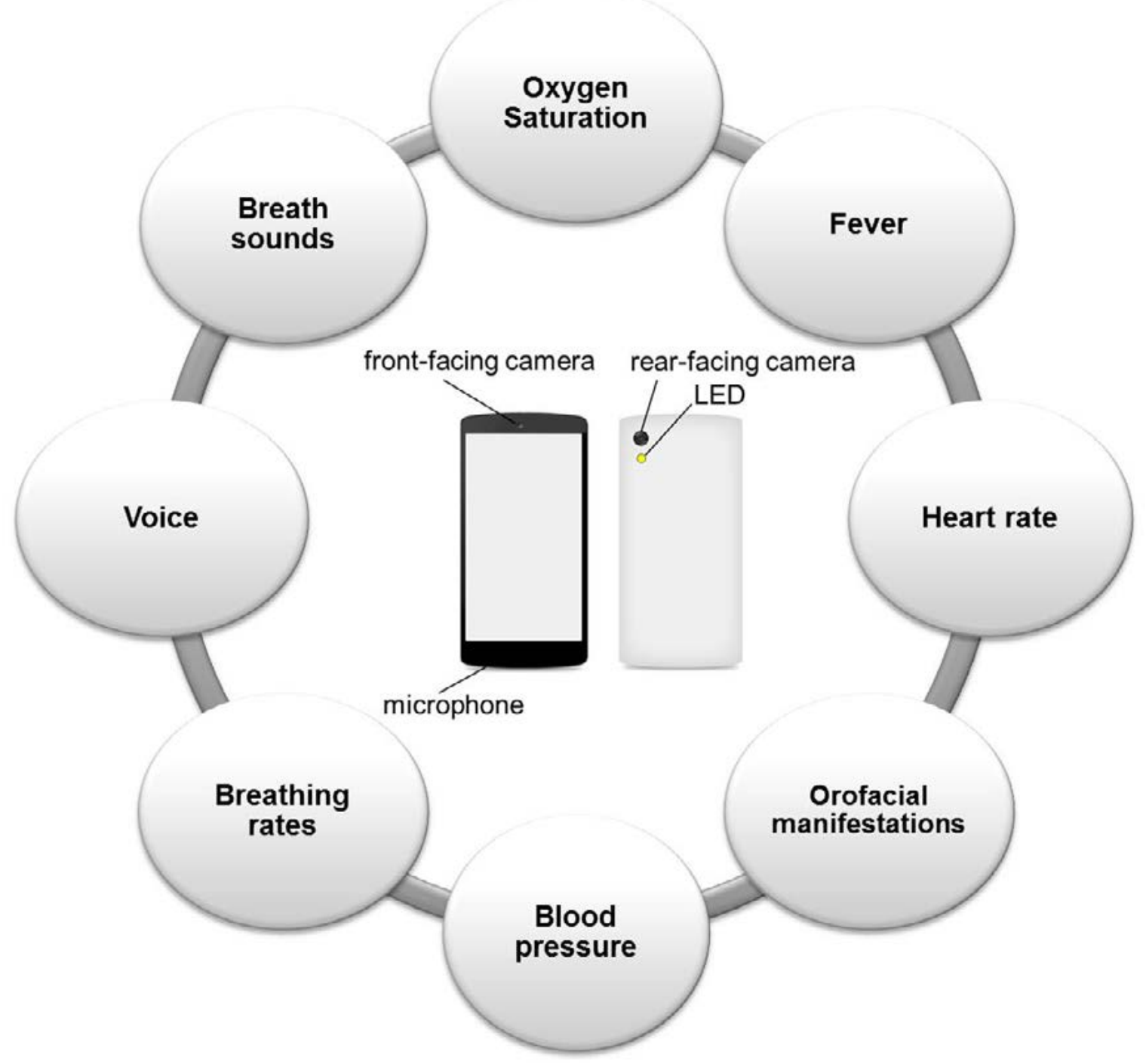

Figure 1 - Clinical parameters that can be assessed using the smartphone to monitor patients with COVID-19

\section{Oxygen saturation with smartphone}

The decrease in oxygen saturation $\left(\mathrm{SpO}_{2}\right)$ is associated with dyspnea and hypoxemia. This condition has been related to a high mortality rate among patients who have been diagnosed with COVID-19. When the $\mathrm{SpO}_{2}$ value is below $93 \%$, oxygen therapy is commonly indicated (18).
A pulse oximeter is a small portable device that allows continuous and non-invasive monitoring of oxygen saturation (19). Red and infrared LEDs (wavelength ranging from 660 to $900 \mathrm{~nm}$ ) are the most commonly used in pulse oximeters (20).

These types of equipment are simple, userfriendly, and intuitive devices that cost around 
\$30. Although these are portable devices that allow non-invasive measurement of $\mathrm{SpO}_{2}$ (21), are still not widespread in the population, being used only by health professionals, while smartphones are used by the majority of the population. In 2018, the number of mobile phones in the world exceeded 5 billion, indicating that almost $70 \%$ of the population has access to a smartphone (22). Brazilians have a preference for this type of device for internet access. In 2014, out of the 36.8 million households observed, 29.6 million accessed the internet via smartphone (23).

Lamonaca et al. (24) in 2015 presented an approach to measure oxygen saturation using only the smartphone's flashlight and camera. The patient's fingertip is videotaped by smartphonebased photoplethysmography with a flashlight (LED emitting white light). The deviation of light is captured by the rear camera of the smartphone (13). Changes in signal strength in the red and green color channels of the frames are analyzed. These channels have a wavelength range of 600nm and $940 \mathrm{~nm}$ respectively and two Photoplethysmography wave profiles are used to assess $\mathrm{SpO}_{2}$. The results showed great similarity when compared with commercial methods (24).

One of the manifestations of COVID-19 pneumonia is silent hypoxia, a condition in which there is a reduction in oxygen saturation, but the patient does not experience respiratory discomfort or pain, common to other types of pneumonia. The virus causes the alveoli to collapse instead of filling with fluid or pus, as in other infections. One way for early detection of silent hypoxia is by using the smartphone, which has shown correction between 96-99\% with a commercial pulse oximeter (21).

\section{Blood pressure with smartphone}

Some infectious diseases, including COVID-19, can lead to hypotension as a manifestation of myocardial or systemic complications (25).
One way to calculate blood pressure using only the smartphone is through photoplethysmography. Similar to $\mathrm{SpO}_{2}$ measurement, video frames are extracted from the patient's fingertip. The red components of the image pixels are used to plot and generate the photoplestimographic waves (signal intensity by time). Artificial intelligence techniques, such as the Artificial Neural Network, are then used to process the signals and estimate blood pressure (13).

Another way to measure blood pressure using the smartphone is to use the value of the transit time of the pulse, using photoplestimographic combined with a phonocardiogram. While Photoplethysmography uses the smartphone's flashlight and camera accessory to extract red signals, the phonocardiogram uses the microphone to record cardiac sounds when the smartphone approaches the chest (26).

\section{Heart and breathing rates with smartphone}

Among people with COVID-19, about 13.8\% evolves with an elevation of respiratory rate. It is common also that people with this disease have changes in the heart rate, indicating the potential of clinical complications and the necessity of close monitorization $(27,28)$.

Smartphones are mostly equipped with two cameras; front and rear. Taking advantage of these technological features, Nam et al used front and rear cameras of smartphones to estimate heart and breathing rates simultaneously. The rear camera was used to film the index finger based on photoplestimography and the heart rate was estimated. The frontal camera was used to estimate the breathing rate using video recordings of movements (expansion and retraction) of the chest and abdomen, as shown in Figure 2 (29). 


\section{A}
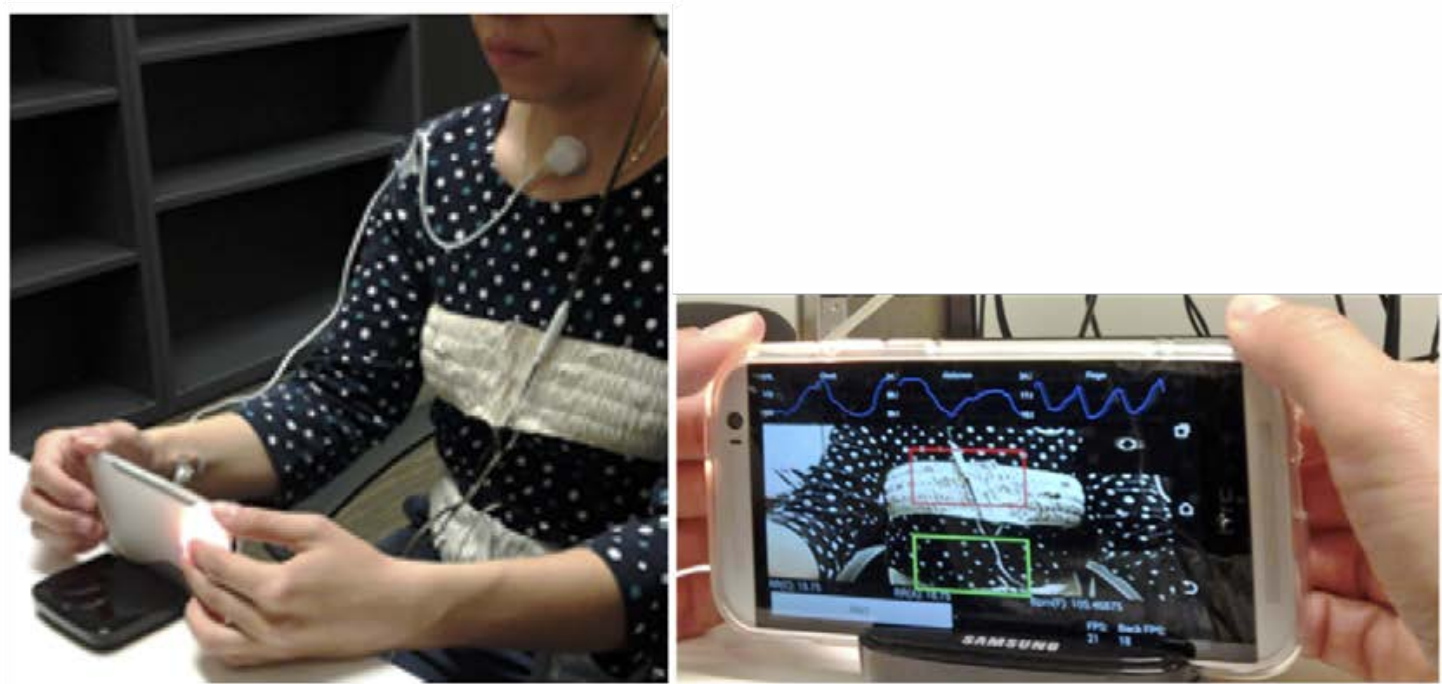

\section{B}

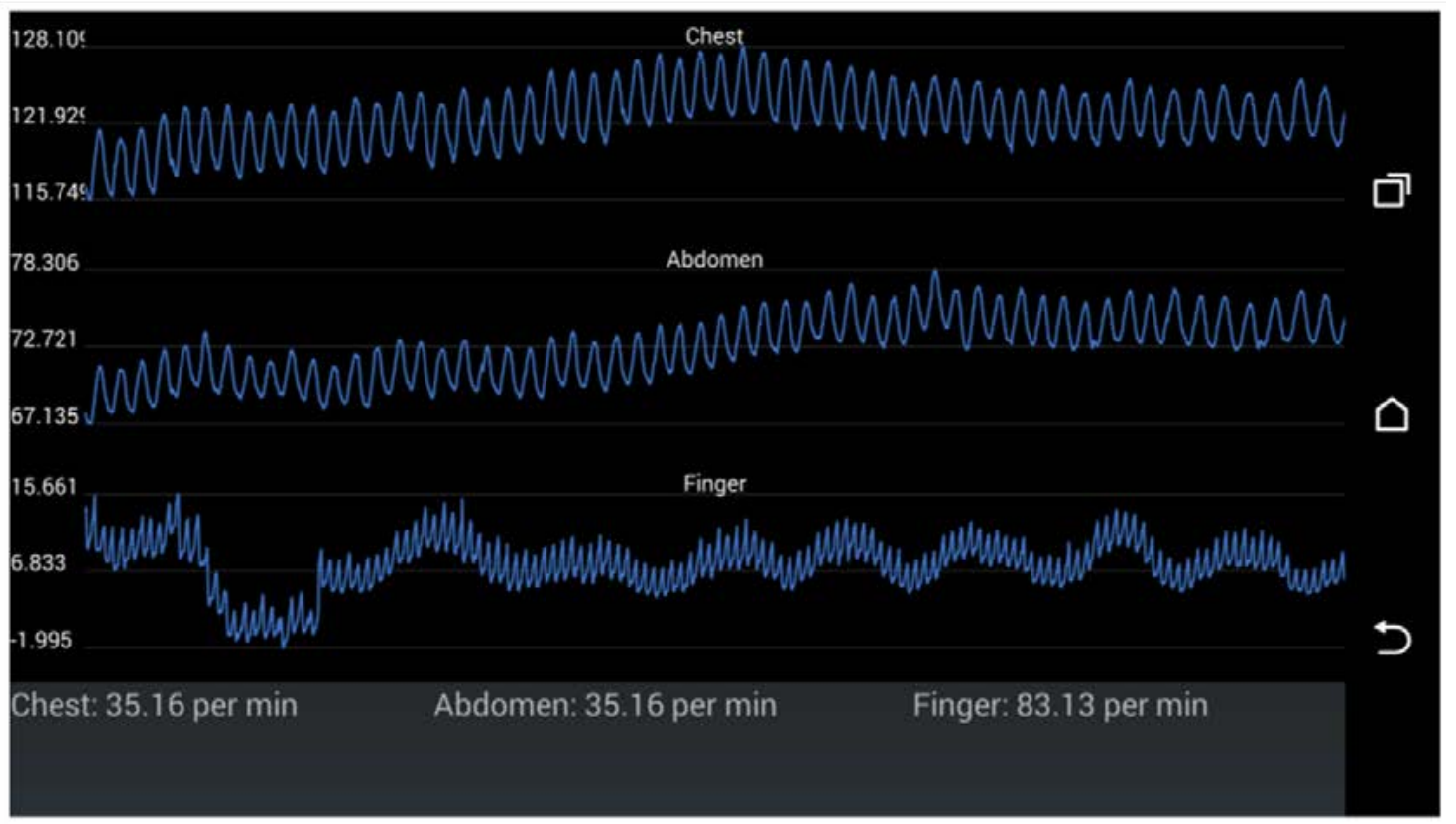

Figure 2 - Estimated heart and breathing rate using the smartphone. A) Position of the index finger on the rear camera covering the entire camera with the flashlight on to estimate the heart rate, and positioning the front camera to capture thoracic and abdominal movements to estimate the breathing rate. B) Time profile of captured waves, heart rate, and respiratory rate values. Reproduced from Nam Y, et al (29) with permission by Creative Commons Attribution 4.0 International License (For interpretation of the references to color in this figure legend, please refer to the web version of the present article).

\section{Breathing sounds and functions with the smartphone}

The use of a smartphone coupled with a microphone allows low-cost analysis of respiratory function. The Spiro Smart is an example of a smartphone app that allowed to perform the spirometry test reliably (30).

The use of a smartphone coupled with a microphone for cardiac auscultation has been reported. The microphone captures sounds and the smartphone processes signals and identifies 
sounds and murmurs that can indicate diseases, such as heart valve diseases (31). One of our hypotheses is that the use of the microphone and smartphone to capture lung sounds could be expanded to detect pneumonia. Although there is no approach developed for this purpose, it is reasonable to imagine that the use of an external microphone on the auscultation points connected by adhesive tape that sends the captured sounds for the smartphone to process could identify the types of noise and classify them as typical of pathology, such as pneumonia. It would be something similar to what happens in auscultation but in a digital way. Lung diseases manifest by different adventitious sounds, for example, continuous wheezing sounds can indicate asthma, rhonchi continuous (bronchitis), discontinuous coarse crackle (chronic bronchitis, bronchiectasis or chronic obstructive pulmonary disease), discontinuous pleural rub (inflammation of lung membrane, lung tumor), continuous gasp (whooping cough), continuous stridor (epiglottitis, foreign body, croup, laryngeal edema), continuous squawk and discontinuous fine crackle may indicate pneumonia. Thus, these last two sounds could indicate a progression of COVID-19.

\section{Fever detected by the smartphone}

Fever is another signal commonly seen in people with COVID-19 (28, 32, 33). Intelligent sensors can transmit body temperature to the smartphone via Bluetooth. These smart thermometers are hardware that consists of a single microcomputer chip associated with an infrared thermometer. This system communicates with smartphones through an installed Android application for interpreting the signal (34). It is expected that, in a short period, smartphone applications will be available to monitor body temperature, and this will certainly involve smartphone-based photoplethysmography or even smartphonebased wearable sensors. At the present moment, the temperature monitoring needs additional hardware and cannot be evaluated using the smartphone alone.

\section{Voice analysis by smartphone}

Voice changes usually indicate respiratory tract disorders. Dysphonia and other otorhinolaryngological symptoms should be part of the symptoms of COVID-19, presenting in a quarter of patients with mild or moderate infection (35). Damaging effects resulting from the new coronavirus and associated diseases can destroy the vagus and the laryngeal nerves, which innervate vocal cords and part of the larynx, impacting motor functions and sensitivity(36).

Uloza et al. (37) assessed the feasibility of using a smartphone's microphone for screening vocal pathologies. The voices of 118 people were recorded, 84 patients (with different diseases that result in voice alteration, including nodules, cysts, carcinoma, and other diseases of the larynx) and 34 non-sick people, using the Smart Voice Recorder application in "wav format" The individuals sustained the vowel "a" for at least five seconds. This method was able to distinguish between pathological voices and healthy ones, as well as tracking voice changes automatically.

\section{Orofacial manifestations photo analysis by smartphone}

The use of photos obtained with a smartphone can also be a useful tool to assess COVID-19, especially in the progression of the disease. Orofacial manifestations may be present in cases of COVID-19 infection, such as ulcerative lesions (38). For example, the color and texture of the tongue can indicate whether a patient is healthy or may be infected with the new coronavirus. Dulam et al used smartphone-based photos from the tongues of individuals and machine learning techniques to classify the tongues of healthy and sick patients. Tongues with characteristics of whitish coloring and textures containing white spots were present in patients with COVID-19 (39).

\section{Final Considerations}

Telemedicine and mHealth apps are powerful tools and can help with health monitoring and disease diagnosis, such as COVID-19. However, it 
is important to emphasize that all these tools and innovations in health are not emerging to replace the medical doctor or clinical knowledge, quite the contrary, these tools are to help the doctor, and are co-supporting clinical practice. Telemedicine, which was already being developed through the use of new technologies for sensing, analyzing, and transferring data, gained significant impulse with the COVID-19 pandemic. Nonetheless, beyond the problem represented by COVID-19, the expanded access to smartphones offers opportunities for the popularization of these technologies and their use for in-person or remote health care. In addition to being able to replace other resources for the capture and analysis of clinical data and to concentrate this possibility in single equipment at a relatively low cost, assisting in face-to-face clinical evaluation, it can help in the transfer of medical data and information over long distances in realtime. This technological possibility may qualify and increase the efficiency, efficacy, and effectiveness of medical care offered to the population, expand people's access to this care and optimize the flow of assistance in health care networks. At the same time, it can be useful for teaching and research in the medical field, streamlining the respective processes, and spreading access.

\section{Notes}

\section{Funding}

This study did not receive financial support from external sources

\section{Conflicts of interest disclosure}

The authors declare no competing interests relevant to the content of this study.

\section{Authors' contributions.}

All the authors declare to have made substantial contributions to the conception, or design, or acquisition, or analysis, or interpretation of data; and drafting the work or revising it critically for important intellectual content; and to approve the version to be published.

\section{Availability of data and responsibility for} the results

All the authors declare to have had full access to the available data and they assume full responsibility for the integrity of these results.

\section{REFERENCES}

1. Kalirathinam D, Guruchandran R, Subramani P. Comprehensive physiotherapy management in covid-19 - a narrative review. Sci Med. 2020;30(1):e38030. https:// doi.org/10.15448/1980-6108.2020.1.38030

2. Mckee M, Stuckler D. If the world fails to protect the economy, COVID-19 will damage health not just now but also in the future. Nat Med. 2020;26:640-42. https:// doi.org/10.1038/s41591-020-0863-y

3. World Health Organization. WHO Coronavirus Disease (COVID-19) Dashboard. [Internet]. 2021; [cited 2021 Mar 24]. Available from: https://covid19.who.int/.

4. Moraes E, Almeida LHA, Giordani E. COVID-19: Cuidados de enfermagem em unidade de terapia intensiva. Sci Med. 2020;30(1):e38468. https://doi. org/10.15448/1980-6108.2020.1.38468

5. Siordia JA. Epidemiology and clinical features of COVID-19: A review of current literature. J Clin Virol. 2020:127:104357. https://doi.org/10.1016/j. jev.2020.104357

6. Lippi G, Plebani M. Laboratory abnormalities in patients with COVID-2019 infection. Clin Chem Lab Med. 2020;58(7):1131-1134 https://doi.org/10.1515/ cclm-2020-0198

7. Zhang Y, Xiao M, Zhang S, Xia P, Cao W; Jiang W, et al. Coagulopathy and Antiphospholipid Antibodies in Patients with Covid-19. N Engl J Med. 2020; 382:e38. https://doi.org/10.1056/NEJMc2007575

8. Hoffman T, Nissen K, Krambrich J, Rönnberg B, Esmaeilzadeh M, Salaneck E, et al. Evaluation of a COVID-19 IgM and IgG rapid test ; an efficient tool for assessment of past exposure to SARS-CoV-2. Infect Ecol Epidemiol. 2020;10(1):1754538. https://doi.org/10 $.1080 / 20008686.2020 .1754538$

9. Mazzu-Nascimento T, Morbioli GG, Milan LA, Silva DF, Donofrio FC, Mestriner CA, et al. Improved assessment of accuracy and performance indicators in paper-based ELISA. Anal Methods. 2017:9(18):2644-53. https://doi. org/10.1039/C7AY00505A

10. Mazzu-Nascimento T, Leão PAGC, Catai JR, Morbioli GG, Carrilho E. Towards low-cost bioanalytical tools for sarcosine assays for cancer diagnostics. Anal Methods. 2016;8:7312-8. https://doi.org/10.1039/C6AY01848C

11. Godoy MF, Ribas-Filho D. O Futuro é Hoje! Int J Nutrology. 2020;13(2):31. https://doi. org/10.1055/s-0040-1716837 
12. Avram R, Olgin JE, Kuhar P, Hughes JW, Marcus GM, Pletcher MJ, et al. A digital biomarker of diabetes from smartphone-based vascular signals. Nat Med. 2020;26:1576-80. https://doi.org/10.1038/\$41591-020$1010-5$

13. Mazzu-Nascimento T, Leal ÂM de O, Nogueirade-Almeida CA, Avó LR da S de, Carrilho E, Silva DF. Non-invasive self-monitoring of blood glucose at your fingertips, literally!: Smartphone-based photoplethysmography. Int J Nutrology. 2020;13(2):4852. https://doi.org/10.1055/s-0040-1716498

14. Mazzu-Nascimento T, Evangelista DN, Abubakar O, Carrilho E, Silva DF, Chachá SGF, et al. Mobile health ( $m$ Health) and advances in non-invasive diagnosis of anemia: An Overview. Int J Nutrology. 2020;13(2):42-7. https://doi.org/10.1055/s-0040-1716497

15. Caetano R, Silva AB, Guedes ACCM, de Paiva CCN, da Rocha Ribeiro G, Santos DL, et al. Challenges and opportunities for telehealth during the COVID-19 pandemic: Ideas on spaces and initiatives in the Brazilian context. Cad Saude Publica. 2020;36(5):e00088920. https://doi.org/10.1590/0102-311X00088920

16. lyengar K, Upadhyaya GK, Vaishya R, Jain V. COVID-19 and applications of smartphone technology in the current pandemic. Diabetes Metab Syndr Clin Res Rev. 2020;14:733-7. https://doi.org/10.1016/j.dsx.2020.05.033

17. Woo Baidal JA, Chang J, Hulse E, Turetsky R, Parkinson K, Rausch JC. Zooming Toward a Telehealth Solution for Vulnerable Children with Obesity During Coronavirus Disease 2019. Obesity. 2020;28(7):1184-6. https://doi.org/10.1002/oby.22860

18. Xie J, Covassin N, Fan Z, Singh P, Gao W, Li G, et al. Association Between Hypoxemia and Mortality in Patients With COVID-19. Mayo Clin Proc. 2020;95(6):10946. https://doi.org/10.1016/i.mayocp.2020.04.006

19. Nascimento IP, Leite LCC. Recombinant vaccines and the development of new vaccine strategies. Brazilian J Med Biol Res. 2012;45(12):1102-11. https:// doi.org/10.1590/S0100-879X2012007500142

20. Kamshilin AA, Margaryants NB. Origin of Photoplethysmographic Waveform at Green Light. Phys Procedia. 2017:86:72-80. http://dx.doi.org/10.1016/i. phpro.2017.01.024

21. Teo J. Early Detection of Silent Hypoxia in Covid-19 Pneumonia Using Smartphone Pulse Oximetry. J Med Syst. 2020;44:134. https://doi.org/10.1007/s10916-020-01587-6

22. Guede-Fernández F, Ferrer-Mileo V, Mateu-Mateus M, Ramos-Castro J, Garcia-González MÁ, FernándezChimeno M. A photoplethysmography smartphonebased method for heart rate variability assessment: device model and breathing influences. Biomed Signal Process Control. 2020:57:101717. https://doi. org/10.1016/j.bspc.2019.101717
23. Bertollo M. A dinâmica na rede urbana brasileira atual e a capilarização da informação pelo smartphone no território. GEOUSP Espaço e Tempo. 2019;23(2):26284.https://doi.org/10.11606/issn.2179-0892. geousp.2019.158181

24. Lamonaca F, Carni DL, Grimaldi D, Nastro A, Riccio $M$, Spagnolo $V$. Blood oxygen saturation measurement by smartphone camera. In: Grassini S, Groza V, De Vito L, editors. 2015 IEEE - International Symposium on Medical Measurements and Applications (MeMeA) Proceedings; 2015 May 7-9; Turin, Italy. Piscataway: IEEE; 2015 P. 35964. https://doi.org/10.1109/MeMeA.2015.7145228

25. Costa JA, Silveira J de A, Santos SCM, Nogueira PP. Cardiovascular Implications in Patients Infected with Covid-19 and the Importance of Social Isolation to Reduce Dissemination of the Disease. Arq Bras Cardiol. 2020;114(5):834-8. https://doi.org/10.36660/abc.20200243

26. Nemcova A, Jordanova I, Varecka M, Smisek R, Marsanova L, Smital L, et al. Monitoring of heart rate, blood oxygen saturation, and blood pressure using a smartphone. Biomed Signal Process Control. 2020;59:101928. https://doi.org/10.1016/j. bspc.2020.101928

27. Albuquerque J, Neto DF, Marcondes-braga FG, Moura LZ, Melo A, Figueiredo D, et al. Coronavirus Disease 2019 and the Myocardium. Arq Bras Cardiol. 2020;114(6):10517. https://doi.org/10.36660/abc.20200373

28. Lima CMA de O. Information about the new coronavirus disease (COVID-19). Radio Bras. 2020:53(2):VVI. http://dx.doi.org/10.1590/0100-3984.2020.53.2e1

29. Nam Y, Kong Y, Reyes B, Reljin N, Chon KH. Monitoring of heart and breathing rates using dual cameras on a smartphone. PLoS One. 2016;11(3):e0151013. https:// doi.org/10.1371/journal.pone. 0151013

30. Larson EC, Goel M, Boriello G, Heltshe S, Rosenfeld M, Patel SN. SpiroSmart: Using a Microphone to Measure Lung Function on a Mobile Phone. In: Key AK, Chu $\mathrm{HH}$, Hayes G, editors. UbiComp '12: Proceedings of the 2012 ACM Conference on Ubiquitous Computing: 2012 Sep 5-8; Pittsburgh, USA. New York: Association for Computing Machinery; 2012. p. 280-9. https://doi. org/10.1145/2370216.2370261

31. Thoms LJ, Colicchia G, Girwidz R. Phonocardiography with a smartphone. Phys Educ. 2017:52(2):023004. https://doi.org/10.1088/1361-6552/aa51ec

32. Guan W, Ni Z, Hu Y, Liang W, Ou C, He J, et al. Clinical characteristics of coronavirus disease 2019 in China. N Engl J Med. 2020;382(18):1708-20. https://doi. org/10.1056/NEJMoa2002032

33. Chen T, Wu D, Chen H, Yan W, Yang D, Chen G, et al. Clinical characteristics of 113 deceased patients with coronavirus disease 2019: Retrospective study. BMJ. 2020;368:m1091. https://doi.org/10.1136/bmj.m1091 
34. Song W, Yu H, Liang C, Wang Q, Shi Y. Body monitoring system design based on android smartphone. Proc 2012 World Congr Inf Commun Technol WICT 2012. 2012;1147-51. 2012 World Congress on Information and Communication Technologies, Trivandrum, India, 2012, pp. 1147-1151 Publisher: IEEE Institute of Eletrical and Eletronics Engeneer Date of Conference: 30 Oct.-2 Nov. 2012 https://doi.org/10.1109/WICT.2012.6409247

35. Lechien JR, Chiesa-Estomba CM, Cabaraux P, Mat $Q$, Huet K, Harmegnies B, et al. Features of Mild-toModerate COVID-19 Patients With Dysphonia. J Voice. 2020. Epub: 2020 jun 4. https://doi.org/10.1016/j. jvoice.2020.05.012

36. Helding L, Carroll TL, Nix J, Johns MM, LeBorgne WD, Meyer D. COVID-19 After Effects: Concerns for Singerss. J Voice. 2020. Epub 2020 Jun 04 https://doi. org/10.1016/j.jvoice.2020.07.032

37. Uloza V, Padervinskis E, Vegiene A, Pribuisiene R, Saferis V, Vaiciukynas E, et al. Exploring the feasibility of smart phone microphone for measurement of acoustic voice parameters and voice pathology screening. Eur Arch Oto-Rhino-Laryngology. 2015;272(11):3391-9. https://doi.org/10.1007/s00405-015-3708-4

38. Halboub E, Al-Maweri SA, Alanazi RH, Qaid NM, Abdulrab S. Orofacial manifestations of COVID-19: a brief review of the published literature. Braz Oral Res. 2020;34:e124. https://doi.org/10.1590/18073107bor-2020.vol34.0124

39. Dulam S, Ramesh V, Malathi G. Tongue image analysis for COVID-19 diagnosis and disease detection. Int J Adv Trends Comput Sci Eng. 2020;9:7924-8. https:// doi.org/10.30534/ijatcse/2020/145952020

\section{Thiago Mazzu-Nascimento}

BSc in Biomedicine, Ph.D. in Chemistry from the Institute of Chemistry of São Carlos (IQSC) at University of São Paulo (USP), São Carlos, SP, Brazil. Undergraduate medical student and Postdoctoral researcher in Computer Science from the Federal University of São Carlos (UFSCar), São Carlos, SP, Brazil.

\section{Danilo Nogueira Evangelista}

BSc in Biomedicine. Undergraduate medical student from the Federal University of São Carlos (UFSCar), São Carlos, SP, Brazil.

\section{Obeedu Abubakar}

Undergraduate medical student from the Federal University of São Carlos (UFSCar), São Carlos, SP, Brazil.
M.D from Federal University of Juiz de Fora (UFJF), Juiz de Fora, MG, Brazil. Master of Tropical Medicine, Ph.D. in Infectious Diseases and Tropical Medicine from Federal University of Minas Gerais (UFMG), Belo Horizonte, MG, Brazil. Post-Doctorate fellow in Microbiology and Infection from University of Minho, Braga, Portugal. Associate professor in the department of medicine from the Federal University of São Carlos (UFSCar), São Carlos, SP, Brazil.

\section{Lucas Vinicius Domingues}

Undergraduate in Computer Science from the Federal University of São Carlos (UFSCar), São Carlos, SP, Brazil.

\section{Diego Furtado Silva}

BSc, Master, and Ph.D. in Computer Science from Institute of Mathematical and Computer Sciences (ICMC) at University of São Paulo (USP), São Carlos, SP, Brazil. Adjunct professor in the Department of Computer Science from the Federal University of São Carlos (UFSCar), São Carlos, SP, Brazil.

\section{Carlos Alberto Nogueira-de-Almeida}

M.D from University of São Paulo (USP), Master and Ph.D. in pediatrics from University of São Paulo (USP), Ribeirão Preto, SP, Brazil. Director of the Department of Pediatric Nutrology of the Brazilian Association of Nutrology. Adjunct professor in the department of medicine from the Federal University of São Carlos (UFSCar), São Carlos, SP, Brazil.

\section{Correspondence}

Thiago Mazzu-Nascimento

Departamento de Medicina, Universidade Federal de São Carlos.

Rodovia Washington Luis, km 235

São Carlos - SP, Brazil.

ZIP Postal: 13565-905 